\title{
Review
}

\section{A Review of CAM for Procedural Pain in Infancy: Part I. Sucrose and Non-nutritive Sucking}

\author{
Jennie C. I. Tsao ${ }^{1}$, Subhadra Evans ${ }^{1}$, Marcia Meldrum², Tamara Altman ${ }^{1}$ and \\ Lonnie K. Zeltzer ${ }^{1}$ \\ ${ }^{1}$ Pediatric Pain Program, Department of Pediatrics, David Geffen School of Medicine at UCLA and
2John C. Liebeskind History of Pain Collection, Louise M. Darling Biomedical Library, UCLA
}

\begin{abstract}
There is increasing concern regarding the number of painful medical procedures that infants must undergo and the potential risks of alleviating infant pain with conventional pharmacologic agents. This article is Part I of a two-part series that aims to provide an overview of the literature on complementary and alternative (CAM) approaches for pain and distress related to medical procedures among infants up to six weeks of age. The focus of this article is a review of the empirical literature on sucrose with or without non-nutritive sucking (NNS) for procedural pain in infancy. Computerized databases were searched for relevant studies including prior reviews and primary trials. The most robust evidence was found for the analgesic effects of sucrose with or without NNS on minor procedural pain in healthy full-term infants. Despite some methodological weaknesses, the literature to date supports the use of sucrose, NNS and other sweetened solutions for the management of procedural pain in infancy.
\end{abstract}

Keywords: infant-neonate-nonnutritive sucking-procedural pain-sucrose

\section{Introduction}

Infants are frequently subject to unpleasant and painful procedures often performed shortly after birth. Injections of phytonadione, blood collection for testing of disease, immunizations and circumcisions for male infants are all common painful procedures. In addition, preterm or sick infants may undergo multiple painful diagnostic and surgical procedures during their hospital stay. Many such procedures are performed without pain relief, despite infants' clear expressions of pain. Crying, grimacing and increased heart rate, blood pressure and cortisol levels are all evident in infants undergoing spinal tap, circumcision and heel lancing (1). The ability of new born infants to perceive and respond to pain has been known for some time. Despite this acknowledgment, options for

For reprints and all correspondence: Jennie C. I. Tsao, PhD, Pediatric Pain Program, Department of Pediatrics, David Geffen School of Medicine at UCLA, 10940 Wilshire Blvd., Suite 1450, Los Angeles, CA 90024, USA Tel: (310) 824-7667; Fax: (310) 824-0012;

E-mail: jtsao@mednet.ucla.edu infant procedural pain have traditionally been limited, with opioids reserved, and quite legitimately so, for surgical procedures.

There is considerable need for non-invasive and safe methods of infant procedural pain relief. Pain often results in a range of negative responses, including decreased oxygenation and intracranial pressure in babies (2). The ill effects of pain, even minor temporary pain, can further run a protracted course in infants. Painful procedures such as circumcision, performed without pain relief, often have detectable effects in the future (3). Multiple painful procedures can actually result in permanent structural and functional changes, making infants more susceptible to pain and distress in the future (4). It is also ethically important to ensure that pain is minimized, especially in vulnerable groups such as infants and children.

One way that infant pain can be alleviated is through the use of sweet substances either with or without non-nutritive sucking (NNS). The oral administration of sucrose with or without NNS is the most frequently 
investigated non-pharmacological approach for procedural pain in infants. The effects of sucrose and NNS are likely to be mediated by both endogenous opioid and non-opioid systems (5). NNS sucking, typically administered through a pacifier, is also thought to be incompatible with crying and attenuates some physiological responses (6), although the underlying mechanisms of sucrose and NNS are currently not well understood.

Despite the probable use of sucrose and NNS as safe, effective and inexpensive methods of managing infant pain, many painful procedures are still carried out without sufficient management of infant analgesia. As sucrose and NNS are not typical, conventional medical interventions, they can be classified as a form of complementary and alternative medicine (CAM). The present review is an attempt to consolidate the existing empirical research relating to sucrose, and other sweet substances with or without NNS to further understand the pain and administration conditions under which these interventions work best for infants undergoing procedural pain. Other CAM interventions for procedural pain in infants are reviewed in Part II.

\section{Method}

The PubMed, PsychInfo, CINAHL and Cochrane Library databases searched up to August 2006 using the keywords: 'pain', 'infant', 'infancy', 'neonate', 'newborn', 'baby' and 'babies'. Infants included newborns between a few hours and 6-weeks old; reports on pain in older children were excluded [see Tsao and Zeltzer (7) for a review of CAM approaches for pain in older children]. Studies examining the analgesic effects of sucrose and other sweet solutions with or without NNS were included if they possessed a control group or a comparison condition (e.g. at least one other intervention). Due to the large number of trials uncovered using the present search strategy, reviews by the Cochrane Collaboration and other authors were summarized when available. In addition, key primary investigations that were not included in the Cochrane or other reviews, or that have been published since those reviews appeared are also discussed. Where no existing reviews could be located, results from the primary trials are described. Results of the studies included in this review are summarized in Tables 1-3.

\section{Summary of Studies Using Sucrose and NNS}

\section{Use of Sucrose and NNS for Minor Procedures (Heel Lance/Venipuncture)}

The findings of investigations on the use of sucrose with or without (NNS) (e.g. pacifiers) for minor procedural pain are displayed in Table 1. A recent Cochrane review by Stevens and colleagues (8) included 21 trials
(1616 infants) which used sucrose with and without NNS for procedural pain. The general finding from this review was that sucrose resulted in decreased physiological (heart rate) and behavioral (cry behaviors; facial action) indices of pain as well as reductions in composite pain scores. For example, in three reports (9-11) which used the Premature Infant Pain Profile (PIPP) (12) as an outcome measure, sucrose led to significantly reduced pain scores following heel lancing relative to control conditions (Table 1). The Cochrane review concluded that sucrose is a safe and effective intervention for minor procedural pain in infants. The authors further concluded that the greatest analgesic effect was found when sucrose is given approximately $2 \mathrm{~min}$ prior to the start of the painful procedure (13). This interval is thought to coincide with endogenous opioid release (8). The Cochrane review further concluded that repeated doses throughout the procedure may be more beneficial than a single dose (10), but additional work is required to quantify the number of optimal doses.

The authors of the Cochrane review (8) also pointed to important limitations to the above findings. Most of the investigations included small sample sizes, and there was a general lack of information regarding randomization processes. It was also noted that because insufficient information was given regarding the procedures, it was difficult to compare the intensity, frequency or duration of procedures across studies. Moreover, many of the investigators did not adequately define 'pain', nor did they provide a conceptual framework for how the measured outcomes were related to pain response. An evaluation of adverse effects was reported in only 6 of the 21 trials, although these effects were minor and did not require additional interventions. Since the majority of procedures included in the Cochrane review involved heel lancing, it was recommended that additional research be conducted on other medical procedures. It was also noted that more work is needed to examine the use of sucrose combined with other behavioral and pharmacological approaches for more invasive procedures.

\section{NNS Alone is Beneficial for Pain Management in Healthy Term Infants}

As shown in Table 2, a number of investigations have examined the use of NNS (e.g. pacifier alone) without sucrose for minor procedural pain. One meta-analysis (14) included three studies testing the use of NNS alone for pain related to needle insertions or heel sticks $(6,15,16)$ (Table 2). It was noted that the total weighted effect size (i.e. adjusted for number of subjects) of NNS on heart rate combined across the three analyses was 1.05 , a large effect. These findings led to the conclusion that NNS appears to have a beneficial effect in reducing heart rate in infants during minor procedures. The authors speculated that the underlying mechanism for 
Table 1. Studies using Sucrose with or without NNS for Minor Procedures

\begin{tabular}{|c|c|c|c|c|c|c|c|}
\hline Study & Procedure & Participants & Randomized & CAM approach & Control & Outcome measures & Findings \\
\hline $\begin{array}{l}\text { Blass and } \\
\text { Hoffmeyer (1) }\end{array}$ & $\begin{array}{l}\text { 1) Heel stick } \\
\text { 2) Circumcision }\end{array}$ & 54 term & Yes & $\begin{array}{l}\text { 1) } 12 \% \text { sucrose } \\
\text { 2) } 24 \% \text { sucrose } \\
+ \text { pacifier }\end{array}$ & $\begin{array}{l}\text { 1) Water } \\
\text { 2) No intervention }\end{array}$ & Crying duration & $\begin{array}{l}\text { 1) Sucrose }<\text { control } \\
\text { 2) Sucrose }+ \text { pacifier } \\
\text { pacifier }<\text { control }\end{array}$ \\
\hline $\begin{array}{l}\text { Blass and } \\
\text { Shah (13) }\end{array}$ & Heel stick & 72 term & $?$ & $\begin{array}{l}\text { 1) Sucrose } 2 \text { doses } 60 \mathrm{~s} \\
\text { prior to procedure } \\
\text { 2) Sucrose }(30,60,90 \text {, } \\
120,240 \mathrm{~s} \text { prior) }\end{array}$ & $\begin{array}{l}\text { 1) Water } \\
\text { 2) Untreated }\end{array}$ & $\%$ Time crying & $\begin{array}{l}\text { 1)Sucrose (regardless of dose) } \\
<\text { control } \\
\text { 2)Most effective delay } \\
=120 \mathrm{sec}\end{array}$ \\
\hline $\begin{array}{l}\text { Blass and } \\
\text { Watt }(21)\end{array}$ & Heel stick & 40 term & Yes & $\begin{array}{l}\text { 1) Sucrose } \\
\text { 2) Pacifier + sucrose } \\
\text { 3) Pacifier + water }\end{array}$ & 1) Water & $\begin{array}{l}\text { HR } \\
\% \text { Time crying } \\
\% \text { Time grimacing }\end{array}$ & $\begin{array}{l}\text { Crying, grimacing: pacifier } \\
\quad+\text { sucrose, sucrose alone } \\
\quad<\text { both controls }<\text { pain } \\
\text { when suck rate }>30 \text { sucks } / \text { min }\end{array}$ \\
\hline $\begin{array}{l}\text { Carbajal } \\
\quad \text { et al. (23) }\end{array}$ & Venipuncture & 150 term & Yes & $\begin{array}{l}\text { 1) } 30 \% \text { glucose } \\
\text { 2) } 30 \% \text { sucrose } \\
\text { 3) Pacifier } \\
\text { 4) } 30 \% \text { sucrose } \\
\text { + pacifier }\end{array}$ & $\begin{array}{l}\text { 1) Standard care } \\
\text { 2) Water }\end{array}$ & DAN scale & $\begin{array}{l}\text { Pain: sucrose }+ \text { pacifier }<\text { pacifier } \\
\text { only }<\text { sucrose, glucose }<\text { no } \\
\text { treatment, placebo }\end{array}$ \\
\hline $\begin{array}{l}\text { Johnston } \\
\text { et al. (10) }\end{array}$ & Heel stick & 48 preterm & Yes & $\begin{array}{l}\text { 1) Single dose } 24 \% \\
\text { sucrose } \\
\text { 2) Multiple doses }\end{array}$ & Water & PIPP & Repeated dose $<$ single dose, control \\
\hline $\begin{array}{l}\text { Stevens } \\
\quad \text { et al. (11) }\end{array}$ & Heel stick & 122 VLBW & Yes & $\begin{array}{l}\text { 1) Sucrose + pacifier } \\
\text { 2) Pacifier + water } \\
\text { 3) containment }\end{array}$ & Standard care & PIPP & $\begin{array}{l}\text { Pain: sucrose + pacifier, water } \\
\quad+\text { pacifier }<\text { others (containment; } \\
\text { control) }\end{array}$ \\
\hline Abad et al. (41) & Venipuncture & 51 term & Yes & $\begin{array}{l}\text { 1) Sucrose } \\
\text { 2) EMLA } \\
\text { 3) Sucrose + EMLA }\end{array}$ & Water & $\begin{array}{l}\text { Crying time } \\
\mathrm{HR} \\
\text { Respiratory } \\
\quad \text { rate } \mathrm{SaO} 2\end{array}$ & $\begin{array}{l}\text { Crying: sucrose, sucrose + EMLA } \\
\quad<\text { control or EMLA alone }\end{array}$ \\
\hline $\begin{array}{l}\text { Gormally } \\
\text { et al. }(25)\end{array}$ & Heel stick & 85 term & Yes & $\begin{array}{l}\text { 1) Sucrose } \\
\text { 2) Holding + water } \\
\text { 3) Holding + sucrose }\end{array}$ & Water & $\begin{array}{l}\text { NFCS } \\
\text { Crying } \\
\text { HR } \\
\text { Vagal Tone }\end{array}$ & $\begin{array}{l}\text { Pain: holding }+ \text { water }<\text { others } \\
\text { Crying: holding }+ \text { sucrose }<\text { others } \\
\text { (no interaction effect: additive) } \\
\text { HR: holding + sucrose }<\text { others } \\
\text { (only for infants with high } \\
\text { preintervention HR) }\end{array}$ \\
\hline $\begin{array}{l}\text { Akman } \\
\quad \text { et al. (22) }\end{array}$ & Heel stick & 138 term & $?$ & $\begin{array}{l}\text { 1) Dextrose } 12.5 \% \\
\text { 2) Dextrose + pacifier } \\
\text { 3) Sucrose } 12.5 \% \\
\text { 4) Sucrose + pacifier }\end{array}$ & Water & $\begin{array}{l}\text { NFCS } \\
\text { Crying time }\end{array}$ & $\begin{array}{l}\text { Pain, crying time: sucrose }+ \text { pacifier, } \\
\text { glucose }+ \text { pacifier }<\text { dextrose } \\
\text { sucrose }<\text { contro }\end{array}$ \\
\hline $\begin{array}{l}\text { Gibbins } \\
\quad \text { et al. (9) }\end{array}$ & Heel stick & 190 preterm + term & Yes & $\begin{array}{l}\text { 1) Sucrose + pacifier } \\
\text { 2) Sucrose }\end{array}$ & Water + pacifier & $\begin{array}{l}\text { PIPP } \\
\text { Adverse events }\end{array}$ & $\begin{array}{l}\text { Pain: sucrose }+ \text { pacifier }<\text { others } \\
\text { Few adverse events }\end{array}$ \\
\hline $\begin{array}{l}\text { Storm and } \\
\quad \text { Fremming (29) }\end{array}$ & Heel stick & 48 preterm & Yes & $\begin{array}{l}\text { 1) } 15 \% \text { sucrose } \\
\text { 2) } 25 \% \text { sucrose } \\
\text { 3) Milk }+25 \% \text { sucrose }\end{array}$ & $\begin{array}{l}\text { 1)Water } \\
\text { 2) Milk }\end{array}$ & $\begin{array}{l}\text { Crying time } \\
\text { NBAS-arousal } \\
\text { HR }\end{array}$ & $\begin{array}{l}\text { Crying: sucrose, milk, milk } \\
\quad+\text { sucrose }<\text { water } \\
\text { Arousal: milk }+25 \% \text { sucrose } \\
\quad<\text { others }\end{array}$ \\
\hline
\end{tabular}

(Continued) 


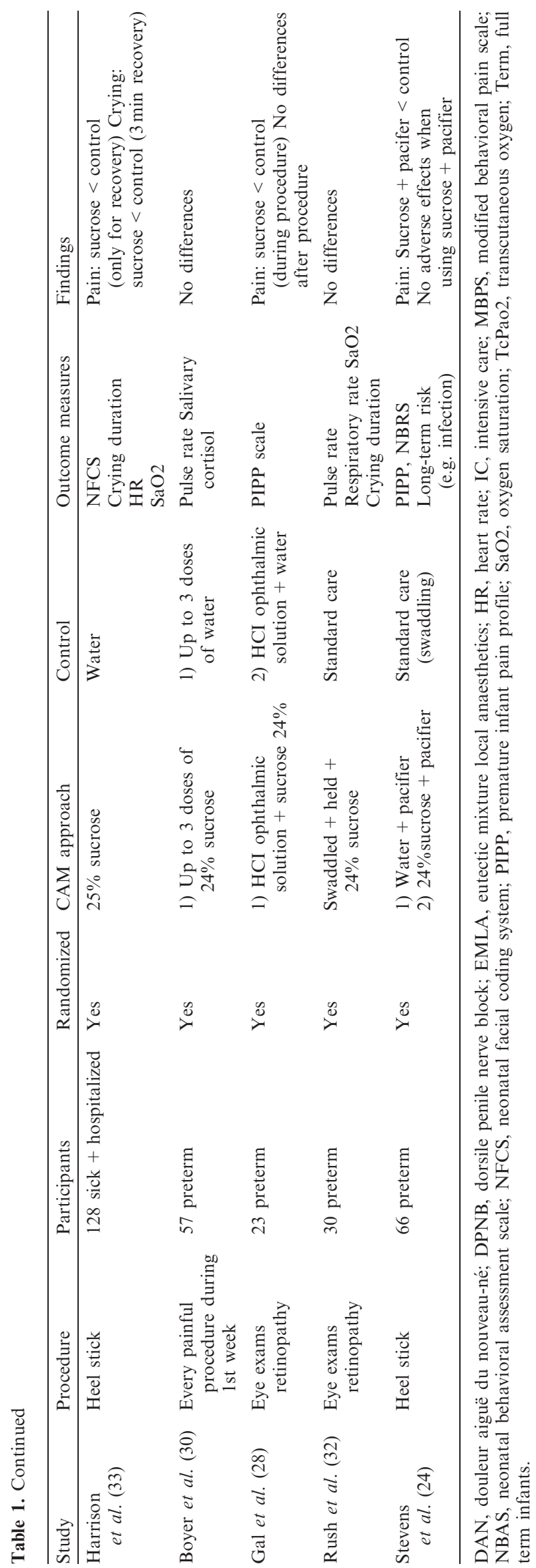

this effect may be the influence of NNS on cardiac vagal tone (14). An important caveat to these findings is that one of the three trials used non-random assignment (15). Non-random assignment increases the possibility that the positive results may have been due to factors other than the intervention.

More recently, a review by Pinelli and colleagues (17) concluded that the overall effects of NNS on pain related to minor procedures were generally superior to standard care. The reports included in this review found that relative to standard care, NNS resulted in reduced cry behavior $(16,18)$, reduced heart rate $(16,18)$ and lower behavioral distress $(6,18)$. However, several methodological problems were also noted by Pinelli et al. For example, Miller and Anderson (16), evaluated cry behaviors using a subjective, unvalidated scale.

\section{Additive Effects of Sucrose and NNS on Minor Procedural Pain}

Data derived from several investigations suggest that the effects of sucrose and NNS may be additive. In the Cochrane review on sucrose and NNS discussed above, Stevens et al. (8) noted that for management of pain related to minor procedures, the use of a pacifier for sucrose delivery may promote NNS, which may help reduce pain-related distress (19) and enhance calming effects (20). Decreased pain has been associated with NNS greater than 30 sucks per minute (21); it is possible that combining sucrose together with pacifiers works by increasing NNS and thereby analgesia. As Table 1 shows, in healthy, full-term infants, studies comparing the effects of NNS alone, sucrose alone and NNS with sucrose generally find the combination of the two approaches to be the most effective $(1,22,23)$. However, Blass and Watt (21) found that sucrose with or without NNS was equally beneficial and both were superior to pacifier alone and water alone (see Table 1). In preterm infants, it has also been reported that the provision of sucrose and a pacifier is more effective than sucrose alone in reducing procedural pain as measured by the PIPP in three reports $(9,11,24)$. Nevertheless, Stevens et al. (8) maintained that the calming effects of NNS have not been shown to continue after cessation of contact whereas the benefits of sucrose has been found to persist for several minutes beyond the cessation of contact (8).

Evidence of the additive effect on pain relief for minor procedures extends to investigations that combine sucrose and other stimuli. Gormally et al. (25) reported that the combination of sucrose and holding infants was most effective in lowering heart rate and crying, followed by sucrose alone and holding alone (Table 1). The work of Bellieni and colleagues $(26,27)$ further shows the effectiveness of combining sucrose with other non-pharmacological interventions. These results suggest that 
Table 2. Studies using NNS and other sweet solutions with or without NNS for minor procedures

\begin{tabular}{|c|c|c|c|c|c|c|c|}
\hline$\underline{\text { Study }}$ & Procedure & Participants & Randomized & CAM approach & Control & Outcome measures & Findings \\
\hline Field and Goldson (6) & Heel stick & $\begin{array}{l}48 \text { preterm } \\
48 \text { pre-IC } \\
48 \text { term }\end{array}$ & Yes & Pacifier (NNS) & Standard care & $\begin{array}{l}\text { NBAS } \\
\text { HR } \\
\text { Respiration }\end{array}$ & $\begin{array}{l}\text { Crying: pacifier < control } \\
\text { HR and respiration: pacifier } \\
\text { < control (for minimal } \\
\text { care preterms) }\end{array}$ \\
\hline \multirow[t]{2}{*}{ Campos (15) } & a) Heel stick & a) 32 2-week-old & No & $\begin{array}{l}\text { Pacifier (NNS) } \\
\text { versus Swaddling }\end{array}$ & None & Crying & $\begin{array}{l}2 \text { week-olds: crying, HR: pacifier } \\
<\text { swaddling }\end{array}$ \\
\hline & b) Injection & b) 32 2-month-olds & & & & HR & $\begin{array}{l}\text { Both groups: HR, crying: } \\
\text { pacifier > recovery }\end{array}$ \\
\hline $\begin{array}{l}\text { Miller and } \\
\text { Anderson (16) }\end{array}$ & $\begin{array}{l}\text { Intravenous } \\
\text { catheter } \\
\text { insertion }\end{array}$ & 10 pre-and full term & Yes & Pacifier (NNS) & Standard care & Crying HR & Crying, HR: pacifier $<$ control \\
\hline Corbo et al. (18) & Heel stick & 23 preterm 3 term & Yes & Pacifier (NNS) & Standard care & NBAS $\mathrm{HR}, \mathrm{SaO} 2$ & $\begin{array}{l}\text { Crying time and HR: } \\
\text { pacifier }<\text { control }\end{array}$ \\
\hline Bucher et al (36) & Heel stick & 80 term & Yes & $\begin{array}{l}\text { 1) Artificial sweetener } \\
\text { 2) Expressed breast milk } \\
\text { 3) Glycerine }\end{array}$ & Water & $\begin{array}{l}\% \text { time crying } \\
\text { Recovery time } \\
\text { Face/body pain HR }\end{array}$ & $\begin{array}{l}\text { Crying/recovery time: } \\
\quad \text { sweetener }<\text { others } \\
\text { HR recovery: sweetener }>\text { others }\end{array}$ \\
\hline Bilgen et al. (38) & Heel stick & 30 term & Yes & $\begin{array}{l}\text { 1) } 25 \% \text { Sucrose } \\
\text { 2) Breast milk } \\
\text { 3) Breast feeding }\end{array}$ & Water & $\begin{array}{l}\text { IBCS } \\
\text { Crying time } \\
\text { HR }\end{array}$ & $\begin{array}{l}\text { Pain: sucrose }<\text { breastfed, } \\
\text { milk, control Crying: } \\
\text { sucrose }<\text { others }\end{array}$ \\
\hline Carbajal et al. (4) & $\begin{array}{l}\text { Subcutaneous } \\
\text { injections }\end{array}$ & 39 preterm & & $\begin{array}{l}\text { Trial 1: } 30 \% \text { glucose } \\
\text { Trial 2: } 30 \% \text { glucose versus } \\
\text { 30\% glucose }+ \text { pacifier }\end{array}$ & Trial 1: water & DAN scale & $\begin{array}{l}\text { 1: Pain: glucose }<\text { control } \\
\text { 2: No differences in glucose groups }\end{array}$ \\
\hline Gradin et al. (42) & Venipuncture & 201 term & Yes & Glucose & EMLA cream + water & $\begin{array}{l}\text { Crying time PIPP } \\
\text { Change in HR }\end{array}$ & Crying, PIPP: glucose $<$ control \\
\hline Carbajal et al. (37) & Venipuncture & 180 term & Yes & $\begin{array}{l}\text { 1) Breast feeding } \\
\text { 2) Held in mother's arms } \\
\text { 3) } 30 \% \text { glucose }+ \text { pacifier }\end{array}$ & Water & $\begin{array}{l}\text { DAN } \\
0 . P I P P\end{array}$ & $\begin{array}{l}\text { Pain: glucose }+ \text { pacifier, } \\
\quad \text { breastfeeding }<\text { others }\end{array}$ \\
\hline Gradin et al. (40) & Venipuncture & 120 term & Yes & $\begin{array}{l}\text { 1) Breastfed }+30 \% \text { glucose } \\
\text { 2) Fasting }+30 \% \text { glucose }\end{array}$ & $\begin{array}{l}\text { 1) Breast fed + placebo } \\
\text { 2) Fasting + placebo }\end{array}$ & $\begin{array}{l}\text { PIPP } \\
\text { Parent pain assess } \\
\text { Crying time }\end{array}$ & PIPP: glucose groups $<$ controls \\
\hline Akcam (35) & Heel stick & 34 term & Yes & $\begin{array}{l}\text { 1) } 30 \% \text { fructose } \\
\text { 2) } 30 \% \text { glucose }\end{array}$ & Water & $\begin{array}{l}\text { DAN behavioral } \\
\text { pain scale }\end{array}$ & Pain: fructose, glucose $<$ control \\
\hline $\begin{array}{l}\text { Akcam and } \\
\text { Ormeci (34) }\end{array}$ & Heel stick & 60 term & Yes & $\begin{array}{l}\text { 1) } 30 \% \text { glucose by spray } \\
\text { 2) } 30 \% \text { glucose syringe }\end{array}$ & Water by syringe & DAN scale & $\begin{array}{l}\text { Pain: glucose groups }<\text { control } \\
\text { No differences between } \\
\text { two glucose groups }\end{array}$ \\
\hline
\end{tabular}


combining sucrose with other CAM approaches provides enhanced pain relief in an additive manner.

\section{Less Consistent Findings for the use of Sucrose and NNS in Preterm Infants}

Sucrose has been reported to be successful for the management of pain in stable preterm infants during various procedures including eye exams for retinopathy (28) as well as heel sticks $(9,11,24,29)$ (Table 1). However, negative findings in preterm infants, have also been reported. Boyer et al. (30) found no differences between sucrose and placebo in preterm infants undergoing a range of painful procedures including heel stick, although these results may have been due to the limited outcomes-pulse rate and cortisol-that were measured. Given the disconnection between physiological and behavioral pain responses in very young infants (31), the lack of behavioral measures in the Boyer study may have precluded a thorough assessment of pain. Similar null findings were reported by Rush et al. (32) who found that sucrose, when combined with swaddling and holding, had little effect on preterm infants' distress while undergoing retinal exams. Control infants tended to cry for longer, but the trend did not reach significance. On the other hand, the small cell sizes may have attenuated the power to find significant differences between groups.

Taken together, the data from these trials provide mixed support for the analgesic effects of sucrose and NNS in stable preterm infants, with the obtained effects being less consistent than those found for healthy, term infants. The findings are even less clear for sick infants. Field and Goldson (6) found that in a sample of sick and hospitalized infants, NNS was only successful in reducing pain behavior during the recovery period of a heel stick and not during the procedure itself. Similarly, Harrison et al. (33) reported that in full-term hospitalized infants undergoing a heel stick, sucrose only reduced pain and crying during the recovery period relative to a control group given water. Moreover, there were no group differences in physiological responses such as heart rate and oxygen saturation. This was a well-conducted investigation which included adequate randomization of participants, blinding of investigators and the use of validated outcome measures. It is possible that the limited analgesic effect of sucrose reported in these trials was due to the infants' illness. It may be that sick infants require a higher dose of sucrose to experience analgesia, or analgesia occurred but that infants across conditions demonstrated low levels of pain behavior due to reduced energy to cry or exhibit distress.

Mixed Findings for the use of Other Sweet Solutions for Minor Procedural Pain in Infants
As displayed in Table 2, the efficacy of oral sucrose for minor procedural pain extends to other sweet solutions, including glucose by syringe or spray (34), fructose (35) and artificial sweetener (36). Each of these sweet solutions was effective in reducing infant procedural pain compared to placebo (i.e. water). Comparisons between breast milk and sucrose suggest that the effect of breastfeeding is similar to sucrose (37), although it is possible that other stimuli during breastfeeding, including olfactory and tactile responses, contribute to its effectiveness. Bilgen et al. (38) found that when verbal intonations and tactile stimulation associated with breastfeeding were controlled, sucrose appeared to be superior to breast milk in reducing infant pain as assessed by the Infant Body Coding System (IBCS) (39) in response to heel prick. Bucher et al. (36) found that artificial sweetener resulted in reduced pain compared to expressed breast milk, further suggesting that sweet solutions may be more effective than breast milk when delivered in a manner not associated with the experience of breastfeeding.

In contrast to sucrose, which has shown additive effects on pain when paired with NNS, glucose alone appears to be just as effective as glucose added to NNS (4) (Table 2). Carbajal and colleagues (47) assessed the effects of glucose and glucose plus NNS on very preterm infants undergoing subcutaneous injections. Thus, Carbajal et al. (47) employed a different approach to that of most prior work in relation to: treatment (glucose), participants (very premature infants) and manner of painful procedure (subcutaneous injections). Glucose was found to be an effective analgesic regardless of whether or not it was paired with NNS. The findings may be due to particular properties of glucose and/or to the response of very preterm infants. Additive effects may be apparent for glucose combined with other forms of analgesia. In a trial by Gradin et al. (40) using glucose and breastfeeding to manage pain responses in full-term infants undergoing venipuncture, breastfeeding combined with glucose was more effective in reducing infant crying time and pain behavior as measured by the PIPP than either glucose or breastfeeding alone. NNS combined with glucose may not have as powerful an effect as the feeding and comforting mechanisms of breastfeeding, although no existing research has examined this possibility.

\section{Benefits of Sucrose and Other Sweet Solutions are Superior to a Conventional Approach for Minor Procedural Pain}

At least two investigators have found that sucrose and other sweet solutions provide analgesic effects that are comparable or superior to eutectic mixture of local anesthetic (EMLA) cream, an established conventional approach for procedural pain. Abad and colleagues (41) 
reported that sucrose was more effective in reducing infant crying time than EMLA, and moreover, adding EMLA to the use of sucrose did not further increase analgesia. Infant heart rate revealed a similar pattern of findings; differences emerged between sucrose and placebo as well as sucrose combined with EMLA and placebo, but there was no analgesic efficacy of EMLA alone. The Abad study possessed a number of strengths, including randomization and the use of researchers who were blind to participant groups. However, pacifiers were used by some infants, and there was no attempt to control this variable. Therefore, it is unknown whether pacifier use confounded the results. In addition, crying times were relied upon to assess behavioral pain responses; the findings would have been strengthened by the use of a validated behavioral measure. Gradin et al. (42) examined the use of glucose compared to EMLA cream in managing infant venipuncture pain by employing the PIPP as well as an assessment of crying time. Findings revealed that both behavioral measures were reduced in the glucose group relative to the EMLA condition, thus providing further support for the use of sweetened solutions over EMLA cream in managing infant pain.

\section{Sucrose With or Without NNS for Major Procedures (Circumcision)}

The findings of trials testing the effects of sucrose with or without NNS for pain in relation to major procedures such as circumcision are summarized in Table 3 . In general, there has been far less research focusing on the application of sucrose/NNS for major procedural pain compared to the plethora of reports examining minor procedural pain.

\section{Evidence Supports the Analgesic Effects of Sucrose and NNS on Circumcision Pain}

Regarding NNS, an early investigation by Gunnar et al. (43) randomly assigned healthy full-term infants to receive either pacifier or no pacifier during circumcision. Infants' behavioral distress was assessed by two independent observers and inter-rater reliability was high, although it was not possible for raters to be blinded to group assignment. Infants given the pacifier cried significantly less and engaged in less motor activity compared to those who did not receive the pacifier. Although limited due to the small sample size $(n=18)$, these findings provide initial support for the use of NNS for circumcision pain. Positive findings were also reported by Blass and Hoffmeyer (1) who found that infants administered sucrose on a pacifier before and during circumcision cried only $31 \%$ of the time during the procedure compared to no-intervention control infants who cried $67 \%$ of the time. Moreover, use of pacifier alone reduced crying time to $49 \%$, supporting the analgesic effects of NNS alone. One limitation however, is that cry duration (audiotaped) was evaluated by a single coder; use of additional coders would have enhanced reliability.

Stang et al. (44) reported that pacifier with sucrose and DPNB resulted in less behavioral distress compared to pacifier with water and DPNB. Despite using a wellvalidated scale to measure behavioral distress [Brazelton Neonatal Behavioral Assessment Scale (45)], only one rater was used and the use of multiple raters would have strengthened the findings. Herschel et al. (46) assigned term neonates to receive DPNB, sucrose or standard care prior to circumcision. The results indicated that sucrose and DPNB were equally effective in reducing elevations in heart rate and excessive movement, and that both sucrose and DPNB were superior to standard care. Based on these findings, Herschel et al. recommended the use of sucrose when parents and/or physicians are uncomfortable with using DPNB. An important limitation of this report however, was the lack of behavioral measures of pain response.

More recently, Kaufman et al. (47) administered EMLA with either pacifier and sucrose or pacifier and water. Infants were assigned to receive one of two common circumcision procedures (i.e. Mogen; Gomco). EMLA with sucrose was found to be more effective than EMLA with water in reducing crying and facial grimacing during the longer procedure (Gomco). The authors concluded that sucrose and pacifier is more effective than water and pacifier (although pacifier alone is more effective than no intervention). In this well-conducted investigation, raters of behavioral distress were blind to group assignment and inter-coder reliability was $95 \%$. Nevertheless, the behavioral ratings were assessed using a relatively new software program with unknown psychometric properties.

Razmus et al. (48) also found that a combination of interventions was most effective in reducing infant circumcision pain. When comparing the use of sucrose to ring block, dorsal block and EMLA in infants undergoing circumcision, sucrose was more effective than no intervention (although it was not reported whether this difference was statistically significant), but the most effective approach was sucrose combined with a ring or dorsal block. Although a well-validated tool was used to assess pain [Face Legs, Activity, Cry, Consolability Scale (FLACC) (49)], design limitations included questionable randomization of participants, lack of blinding of behavioral raters and no reported interrater reliability. The findings nonetheless provide additional support for the use of sucrose in reducing infant circumcision pain, particularly when combined with conventional analgesic blocks. Most recently, South et al. (50) reported data further supporting the analgesic effects of NNS for circumcision pain. In this controlled 
Table 3. Studies using sucrose with or without NNS for circumcision

\begin{tabular}{|c|c|c|c|c|c|c|c|}
\hline Study & Procedure & Participants & Randomized & CAM & Control & Outcomes & Findings \\
\hline Gunnar et al. (43) & Circumcision & 18 term & Yes & Pacifier & Standard care & Behavior Cortisol & Crying and activity: pacifier $<$ control \\
\hline $\begin{array}{l}\text { Blass and } \\
\text { Hoffmeyer (1) }\end{array}$ & $\begin{array}{l}\text { 1) Heel stick } \\
\text { 2) Circumcision }\end{array}$ & 54 term & Yes & $\begin{array}{l}\text { 1) } 12 \% \text { sucrose } \\
\text { 2) } 24 \% \text { sucrose } \\
+ \text { pacifier }\end{array}$ & $\begin{array}{l}\text { 1) Water } \\
\text { 2) No intervention }\end{array}$ & Crying duration & $\begin{array}{l}\text { 1) Sucrose }<\text { control } \\
\text { 2) Sucrose }+ \text { pacifier }<\text { pacifier }<\text { control }\end{array}$ \\
\hline Stang et al. (44) & Circumcision & 80 term & Yes & $\begin{array}{l}\text { Pacifier }+24 \% \\
\quad \text { sucrose }\end{array}$ & $\begin{array}{l}\text { DPNB + water } \\
\text { dipped pacifier }\end{array}$ & NBAS Cortisol & $\begin{array}{l}\text { Distress: sucrose }<\text { control Time } \\
\text { asleep: sucrose }>\text { control }\end{array}$ \\
\hline Herschel et al. (46) & Circumcision & 119 term & Yes & $\begin{array}{l}\text { 1)DPNB } \\
\text { 2)Oral sucrose }\end{array}$ & Standard care & $\begin{array}{l}\text { Pain movement } \mathrm{SaO} 2 \\
\mathrm{HR}\end{array}$ & $\begin{array}{l}\text { Movement: sucrose, DPNB }<\text { control } \\
\text { HR: sucrose, DPNB }<\text { control }\end{array}$ \\
\hline $\begin{array}{l}\text { Kass and } \\
\text { Holman (3) }\end{array}$ & Circumcision & 71 term & Yes & $50 \%$ dextrose & $\begin{array}{l}\text { 1) Water } \\
\text { 2) DPNB }\end{array}$ & $\begin{array}{l}\text { MBPS } \\
\text { Time crying } \\
\mathrm{HR}, \mathrm{SaO} 2\end{array}$ & $\begin{array}{l}\text { HR: dextrose }>\text { DPNB, water } \\
\text { Pain: DPNB }<\text { dextrose, water }\end{array}$ \\
\hline Kaufman et al. (47) & Circumcision & 57 term & Yes & $\begin{array}{l}\text { EMLA + sucrose } \\
\text { pacifier }\end{array}$ & $\begin{array}{l}\text { EMLA + water } \\
\text { pacifier }\end{array}$ & $\begin{array}{l}\text { Crying time } \\
\text { Grimacing }\end{array}$ & Sucrose $<$ control \\
\hline Razmus et al. (48) & Circumcision & $\begin{array}{l}132 \text { Preterm } \\
+ \text { term }\end{array}$ & ? & $\begin{array}{l}\text { 1) DB + sucrose } \\
\text { 2) DB + sucrose } \\
\text { + EMLA } \\
\text { 3) EMLA + sucrose, } \\
\text { 4) Ring block + sucrose } \\
\text { 5) Sucrose }\end{array}$ & $\begin{array}{l}\text { 1) DB } \\
\text { 2) EMLA } \\
\text { 3) Ring block } \\
\text { 4) No intervention }\end{array}$ & FLACC & $\begin{array}{l}\text { Pain: DB + sucrose, ring block }+ \text { sucrose } \\
\quad<\text { all other groups }\end{array}$ \\
\hline South et al. (50) & Circumcision & 44 term & Yes & $\begin{array}{l}\text { DPNB/tylenol + NNS } \\
\text { (human gloved finger) }\end{array}$ & DPNB/tylenol & Pulse PIPP Cortisol & $\begin{array}{l}\text { Crying time, pain, postprocedure cortisol: } \\
\text { NNS }<\text { control }\end{array}$ \\
\hline
\end{tabular}

DB, dorsal block; FLACC, face, legs, activity, cry, consolability scale. 
trial, infants were randomized to a NNS group with dorsal penile nerve block (DPNB) and Tylenol or a control group administered only DPNB and Tylenol. Compared to the control group, the NNS group evidenced significantly lower behavioral and physiologic pain responses, including crying time and post-procedure cortisol levels.

\section{Limited Evidence for the use of Other Sweet Solutions for Circumcision Pain}

Not all reports, however, indicate beneficial effects of sweetened solutions for circumcision pain in infants. Kass and Holman (3) compared infants from a military hospital who received either $50 \%$ oral dextrose, DPNB or water placebo (see Table 3). Infants who received dextrose exhibited a higher heart rate than those in the DPNB and placebo groups. This counterintuitive result may be explained by higher baseline heart rate in the dextrose group (relative to the other groups) and that an increase in heart rate in response to sugar is common, even for infants not undergoing painful interventions (51). However, Kass and Holman (3) also found that dextrose was less effective than DPNB in reducing pain as measured by the Modified Behavioral Pain Scale (MBPS) (52), a well-validated pain scale for infants 4-6 months of age. The divergence between these findings and research by Herschel et al. (46) showing that sucrose is equally effective as DPNB may be explained by differing delivery methods. While Herschel and colleagues administered sugar via a pacifier or nipple, thereby providing the opportunity for NNS, delivery in the Kass study was via an oral syringe. The other possibility is that dextrose is less effective than sucrose in providing analgesia.

\section{Discussion}

A considerable body of evidence supports the efficacy of sucrose, with or without non-nutritive sucking (NNS), as a non-pharmacological pain-relieving method for minor procedural pain in healthy term infants (Table 1). A recent Cochrane review (8) reported that good evidence exists for the efficacy of oral sucrose given to infants $2 \mathrm{~min}$ prior to heel stick procedures, in reducing both behavioral and physiological pain responses. NNS alone or in combination with sucrose has also been found to reduce physiological pain response and cry behaviors in circumcision relative to standard care or no intervention and to add analgesic effect when used in combination with a conventional analgesic block. Data from existing research further suggests that sucrose is an effective and possibly superior alternative to EMLA, a conventional pharmacological analgesic $(41,42)$. Sucrose has also been found to be superior to breast milk and breast feeding as a procedural analgesic in full-term newborns, when the verbal and tactile cues of nursing are controlled (38).

There is also substantial evidence to suggest that NNS alone reduces elevations in heart rate and pain behavior in response to heel sticks and needle insertions (Table 2). Adding sucrose to the pacifier may increase the rate of sucking and provide an additive effect, as illustrated by the several investigations that have found superior analgesic effects with sucrose combined with NNS, when compared with either intervention alone in both full-term and preterm neonates. However, Stevens et al. (8) has stressed that infants appear to receive continuing benefit from sucrose for several minutes after administration, allowing the performance of one or more painful procedures, while the pacifier relieves distress only while the baby is actually engaged in sucking. Finally, sucrose or another sweet solution may provide an important baseline or additive effect in combination with some other interventions such as holding (25) or sensory stimulation $(26,27)$.

Mixed findings have been reported regarding the use of sucrose in preterm and sick infants. Whereas some investigators have found little difference between sucrose and placebo in reducing preterm infant distress to eye exams (32) and other procedures including heel sticks (30), other researchers have found sucrose an effective analgesic for preterm neonates (Table 1). Findings from the negative studies may have been skewed by small sample size or limited outcome measures. Also, two wellconducted trials of sick infants $(6,33)$ have shown that sucrose administration failed to reduce pain behavior during heel sticks, although sucrose did appear to provide analgesic benefits during recovery. Thus, the benefits obtained from the use of sucrose in alleviating minor procedural pain among preterm or sick infants remain unclear.

Several researchers have demonstrated the effects of other sweet solutions including glucose, fructose and artificial sweetener in reducing minor procedural distress in full-term infants (Table 2). Glucose in particular has been shown to offer equivalent analgesia with or without NNS in very premature infants receiving venipuncture (4) and to provide a significant additive effect to breastfeeding in reducing crying and pain response in full-term infants (40).

On the whole, it appears that sucrose, NNS and sweetened solutions hold considerable promise for reducing infant procedural pain. The findings extend to a number of procedures, including both minor (e.g. heel sticks) and major (i.e. circumcision) procedures. Although it appears that sucrose administered approximately $2 \mathrm{~min}$ before the procedure on a pacifier to induce NNS may be the most consistent form of pain relief, a number of caveats exist. Most researchers have used small sample sizes and failed to report important aspects of their protocols with sufficient clarity, 
such as randomization and procedural standardization. Further well-controlled investigations using validated behavioral pain measures are called for.

\section{Acknowledgments}

Research by the authors is supported in part by R01 DE12754 awarded by the National Institute of Dental and Craniofacial Research (PI: Zeltzer) and R01 MH063779 awarded by the National Institutes of Mental Health (PI: Jacob).

\section{References}

1. Blass EM, Hoffmeyer LB. Sucrose as an analgesic for newborn infants. Pediatrics 1991;87:215-8.

2. Anand KJ, Hickey PR. Pain and its effects in the human neonate and fetus. N Engl J Med 1987;317:1321-9.

3. Kass FC, Holman JR. Oral glucose solution for analgesia in infant circumcision. J Fam Pract 2001;50:785-8.

4. Carbajal R, Lenclen R, Gajdos V, Jugie M, Paupe A. Crossover trial of analgesic efficacy of glucose and pacifier in very preterm neonates during subcutaneous injections. Pediatrics 2002;110:389-93.

5. Gunnar MR, Connors J, Isensee J, Wall L. Adrenocortical activity and behavioral distress in human newborns. Dev Psychobiol 1988;21:297-310.

6. Field T, Goldson E. Pacifying effects of nonnutritive sucking on term and preterm neonates during heelstick procedures. Pediatrics 1984;74:1012-5.

7. Tsao JCI, Zeltzer LK. Complementary and alternative medicine approaches for pediatric pain: a review of the state-of-the-science. Evid Based Complement Alternat Med 2005;2:149-59.

8. Stevens B, Yamada J, Ohlsson A. Sucrose for analgesia in newborn infants undergoing painful procedures. Cochrane Database Syst Rev 2004;CD001069.

9. Gibbins S, Stevens B, Hodnett E, Pinelli J, Ohlsson A, Darlington G. Efficacy and safety of sucrose for procedural pain relief in preterm and term neonates. Nurs Res 2002;51:375-82.

10. Johnston CC, Stremler R, Horton L, Friedman A. Effect of repeated doses of sucrose during heel stick procedure in preterm neonates. Biol Neonate 1999;75:160-6.

11. Stevens B, Johnston C, Franck L, Petryshen P, Jack A, Foster G. The efficacy of developmentally sensitive interventions and sucrose for relieving procedural pain in very low birth weight neonates. Nurs Res 1999:48:35-43.

12. Stevens B, Johnston C, Petryshen P, Taddio A. Premature infant pain profile: development and initial validation. Clin $J$ Pain 1996;12:13-22.

13. Blass EM, Shah A. Pain-reducing properties of sucrose in human newborns. Chem Senses 1995;20:29-35.

14. Shiao SY, Chang YJ, Lannon H, Yarandi H. Meta-analysis of the effects of nonnutritive sucking on heart rate and peripheral oxygenation: research from the past 30 years. Issues Compr Pediatr Nurs 1997;20:11-24.

15. Campos RG. Soothing pain-elicited distress in infants with swaddling and pacifiers. Child Dev 1989;60:781-92.

16. Miller HD, Anderson GC. Nonnutritive sucking: effects on crying and heart rate in incubated infants requiring assisted mechanical ventilation. Nurs Res 1993:42:305-7.

17. Pinelli J, Symington A, Ciliska D. Nonnutritive sucking in high-risk infants: benign intervention or legitimate therapy? J Obstet Gynecol Neonatal Nurs 2002;31:582-91.

18. Corbo MG, Mansi G, Stagni A, Romano A, van den Heuvel J, Capasso L, et al. Nonnutritive sucking during heelstick procedures decreases behavioral distress in the newborn infant. Biol Neonate 2000;77:162-7.

19. Campos RG. Rocking and pacifiers: two comforting interventions for heelstick pain. Res Nurs Health 1994;17:321-31.
20. Blass EM. Behavioral and physiological consequences of suckling in rat and human newborns. Acta Paediatr Suppl 1994;397:71-6.

21. Blass EM, Watt LB. Suckling- and sucrose-induced analgesia in human newborns. Pain 1999;83:611-23.

22. Akman I, Ozek E, Bilgen H, Ozdogan T, Cebeci D. Sweet solutions and pacifiers for pain relief in newborn infants. $J$ Pain 2002;3:199-202.

23. Carbajal R, Chauvet X, Couderc S, Olivier-Martin M. Randomised trial of analgesic effects of sucrose, glucose, and pacifiers in term neonates. Br Med $J$ 1999;319:1393-7.

24. Stevens B, Yamada J, Beyene J, Gibbins S, Petryshen P, Stinson J, et al. Consistent management of repeated procedural pain with sucrose in preterm neonates: Is it effective and safe for repeated use over time? Clin J Pain 2005;21:543-8.

25. Gormally S, Barr RG, Wertheim L, Alkawaf R, Calinoiu N, Young SN. Contact and nutrient caregiving effects on newborn infant pain responses. Dev Med Child Neurol 2001:43:28-38.

26. Bellieni CV, Bagnoli F, Perrone S, Nenci A, Cordelli DM, Fusi M, et al. Effect of multisensory stimulation on analgesia in term neonates: a randomized controlled trial. Pediatr Res 2002;51:460-3.

27. Bellieni CV, Buonocore G, Nenci A, Franci N, Cordelli DM, Bagnoli F. Sensorial saturation: an effective analgesic tool for heel-prick in preterm infants: a prospective randomized trial. Biol Neonate 2001;80:15-8.

28. Gal P, Kissling GE, Young WO, Dunaway KK, Marsh VA, Jones SM, et al. Efficacy of sucrose to reduce pain in premature infants during eye examinations for retinopathy of prematurity. Ann Pharmacother 2005;39:1029-33.

29. Storm H, Fremming A. Food intake and oral sucrose in preterms prior to heel prick. Acta Paediatr 2002;91:555-60.

30. Boyer K, Johnston C, Walker CD, Filion F, Sherrard A. Does sucrose analgesia promote physiologic stability in preterm neonates? Biol Neonate 2004;85:26-31.

31. DiPietro JA, Hodgson DM, Costigan KA, Hilton SC, Johnson TR. Fetal neurobehavioral development. Child Dev 1996;67:2553-67.

32. Rush R, Rush S, Ighani F, Anderson B, Irwin M, Naqvi M. The effects of comfort care on the pain response in preterm infants undergoing screening for retinopathy of prematurity. Retina 2005;25:59-62.

33. Harrison D, Johnston L, Loughnan P. Oral sucrose for procedural pain in sick hospitalized infants: a randomized-controlled trial. J Paediatr Child Health 2003;39:591-7.

34. Akcam M, Ormeci AR. Oral hypertonic glucose spray: a practical alternative for analgesia in the newborn. Acta Paediatr 2004;93:1330-3.

35. Akcam M. Oral fructose solution as an analgesic in the newborn: A randomized, placebo-controlled and masked study. Pediatr Int 2004:46:459-62.

36. Bucher HU, Baumgartner R, Bucher N, Seiler M, Fauchere JC. Artificial sweetener reduces nociceptive reaction in term newborn infants. Early Hum Dev 2000;59:51-60.

37. Carbajal R, Veerapen S, Couderc S, Jugie M, Ville Y. Analgesic effect of breast feeding in term neonates: randomised controlled trial. Br Med $J$ 2003;326:13.

38. Bilgen H, Ozek E, Cebeci D, Ors R. Comparison of sucrose, expressed breast milk, and breast-feeding on the neonatal response to heel prick. $J$ Pain 2001;2:301-5.

39. Craig KD, Whitfield MF, Grunau RV, Linton J, Hadjistavropoulos HD. Pain in the preterm neonate: behavioural and physiological indices. Pain 1993;52:287-99.

40. Gradin M, Finnstrom O, Schollin J. Feeding and oral glucoseadditive effects on pain reduction in newborns. Early Hum Dev 2004;77:57-65.

41. Abad F, Diaz-Gomez NM, Domenech E, Gonzalez D, Robayna M, Feria M. Oral sucrose compares favourably with lidocaineprilocaine cream for pain relief during venepuncture in neonates. Acta Paediatr 2001;90:160-5.

42. Gradin M, Eriksson M, Holmqvist G, Holstein A, Schollin J. Pain reduction at venipuncture in newborns: oral glucose compared with local anesthetic cream. Pediatrics 2002;110:1053-7.

43. Gunnar MR, Fisch RO, Malone S. The effects of a pacifying stimulus on behavioral and adrenocortical responses to circumcision in the newborn. J Am Acad Child Psychiatry 1984;23:34-8. 
44. Stang HJ, Snellman LW, Condon LM, Conroy MM, Liebo R, Brodersen L, et al. Beyond dorsal penile nerve block: a more humane circumcision. Pediatrics 1997;100:E3.

45. Brazelton TB. Neonatal Behavioral Assessment Scale. Philadelphia: Lippincott; 1973.

46. Herschel M, Khoshnood B, Ellman C, Maydew N, Mittendorf R. Neonatal circumcision. Randomized trial of a sucrose pacifier for pain control. Arch Pediatr Adolesc Med 1998;152: 279-84.

47. Kaufman GE, Cimo S, Miller LW, Blass EM. An evaluation of the effects of sucrose on neonatal pain with 2 commonly used circumcision methods. Am J Obstet Gynecol 2002;186:564-8.

48. Razmus IS, Dalton ME, Wilson D. Pain management for newborn circumcision. Pediatr Nurs 2004;30:414-7, 427.
49. Merkel SI, Voepel-Lewis T, Shayevitz JR, Malviya S. The FLACC: a behavioral scale for scoring postoperative pain in young children. Pediatr Nurs 1997:23:293-7.

50. South MM, Strauss RA, South AP, Boggess JF, Thorp JM. The use of non-nutritive sucking to decrease the physiologic pain response during neonatal circumcision: a randomized controlled trial. Am J Obstet Gynecol 2005;193:537-42.

51. Gradin M. Effect of oral glucose on the heart rate of healthy newborns. Acta Paediatr 2005;94:324-8.

52. Taddio A, Nulman I, Koren BS, Stevens B, Koren G. A revised measure of acute pain in infants. J Pain Symptom Manage 1995;10:456-63.

Received February 9, 2007; accepted April 24, 2007 


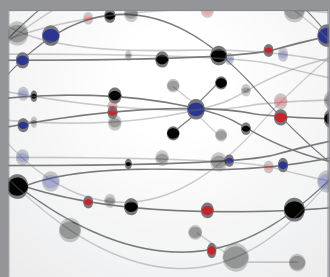

The Scientific World Journal
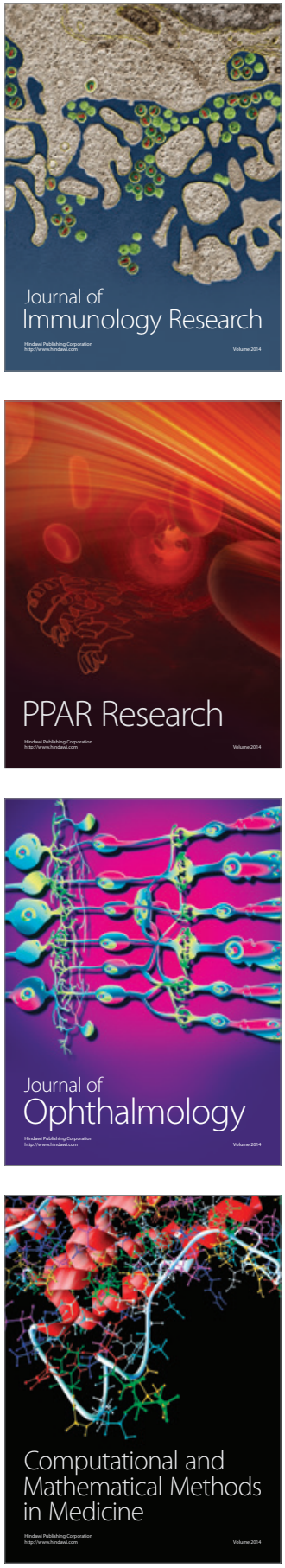

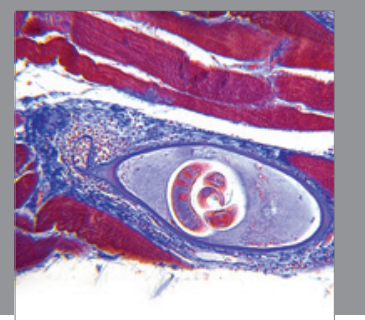

Gastroenterology

Research and Practice
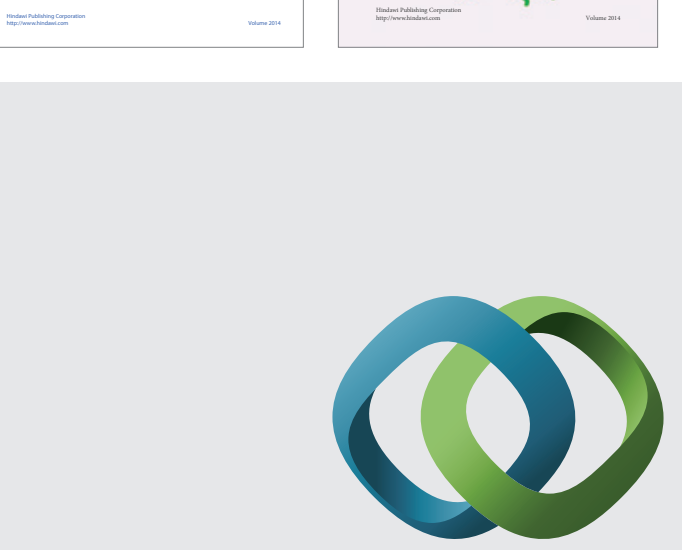

\section{Hindawi}

Submit your manuscripts at

http://www.hindawi.com
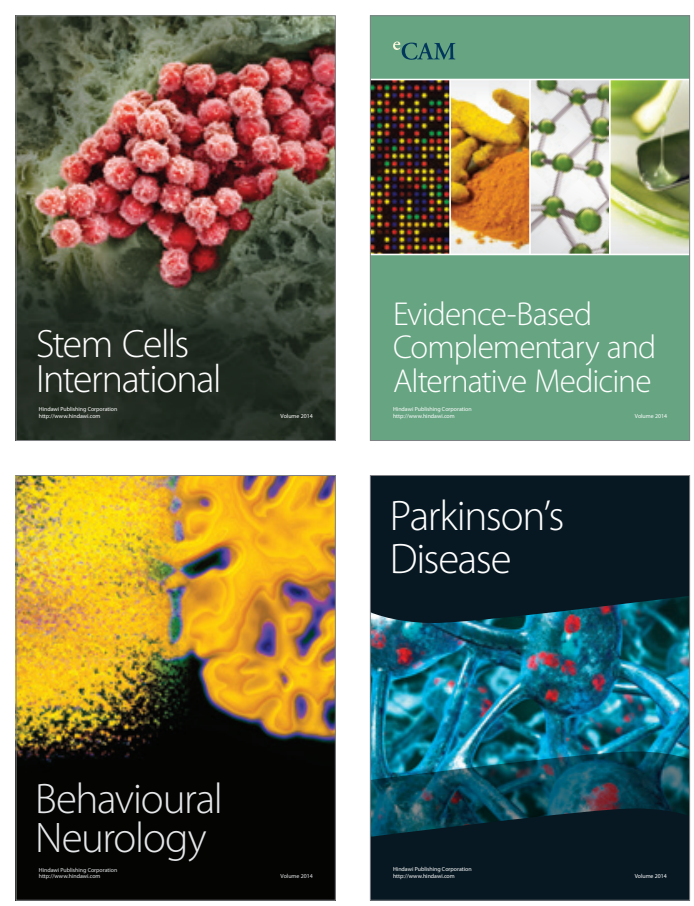

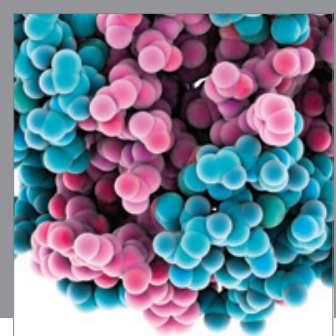

Journal of
Diabetes Research

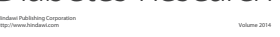

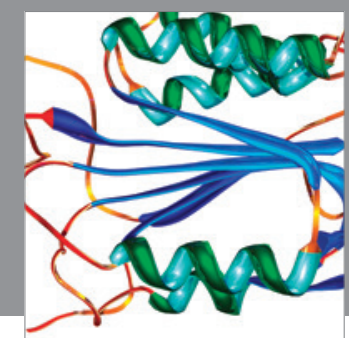

Disease Markers
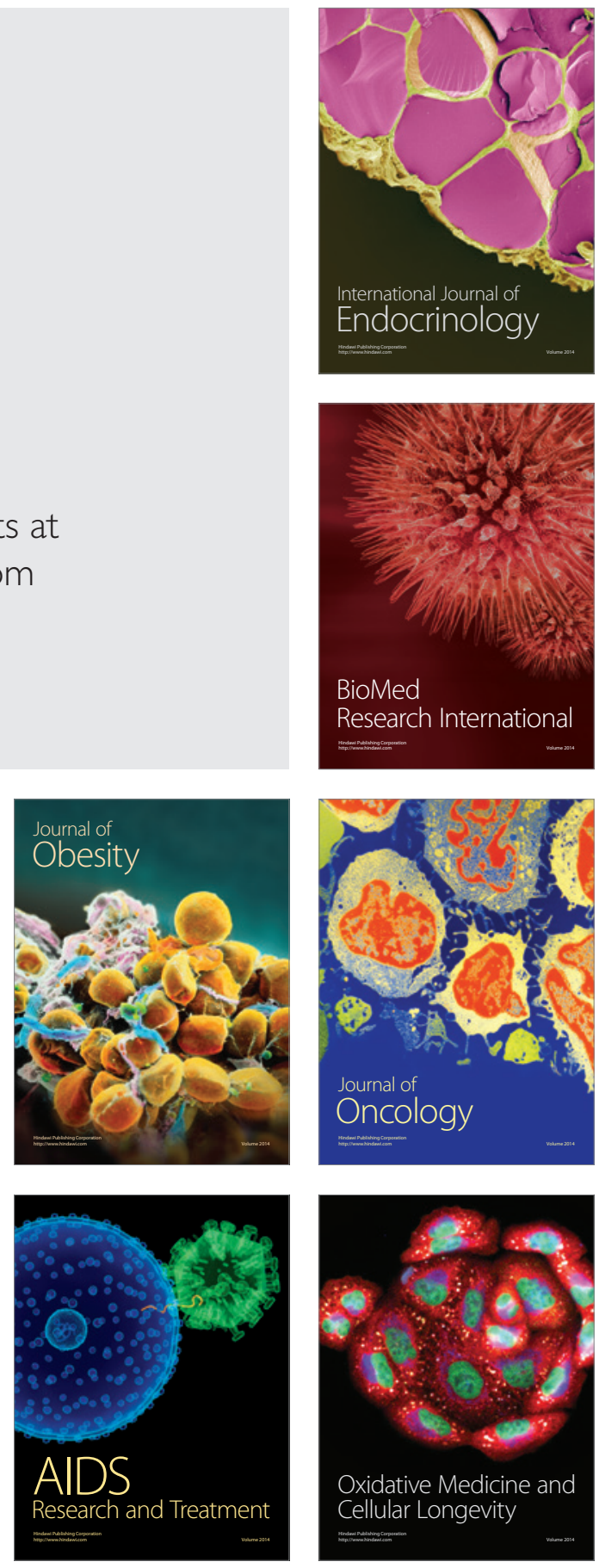